\title{
Learning from The Leadership of Boaz in The Book of Ruth
}

\author{
Sia Kok Sin ${ }^{1) *}$ \\ 1) Theology Department, Sekolah Tinggi Theologi Aletheia, Lawang \\ *) Correspondent author: koksinsia@sttaletheia.ac.id
}

Received: 17 December 2020/ Accepted: 02 June 2021/ Published: 27 September 2021

\begin{abstract}
This article addresses the study of the leadership of Boaz in the book of Ruth by using the leadership concept of Peter G. Northouse. Based on Northouse's concept, Boaz is an ideal and effective leader who can perform both as assigned and emergent leaders. The keys to the success of Boaz's leadership are his character and skills. First, this article will define the leadership concept of Peter G. Northouse. Northouse identifies the nature of leadership as an assigned leadership and emergent leadership. He also explains the powers that associate with the types of leadership. The appointed leadership has position power which consists of legitimate, reward, information, and coercive power. Emergent leadership has personal power that includes referent and expert power. Second, this article will examine the character of Boaz in the book of Ruth through the lens of the nature of leadership as an assigned leadership and emergent leadership. An observation of how Boaz performs the many types of power as an appointed leader and an emergent leader. Finally, this article will conclude how the leadership of Boaz is. Boaz is an ideal and effective leader who can perform both as an assigned and emergent leader. The keys to the success of Boaz's leadership are his character and skills.
\end{abstract}

Keywords: Boaz, Leadership, Peter G. Northouse, The book of Ruth.

\section{Abstrak}

Artikel ini merupakan penyelidikan tentang kepemimpinan Boas dalam kitab Rut dengan menggunakan konsep kepemimpinan oleh Peter G. Northouse. Northouse menyatakan ada 2 natur pemimpin, yaitu pemimpin yang ditugaskan dan pemimpin yang muncul. Boas adalah seorang contoh pemimpin yang ideal dan efektif karena dapat menjalankan perannya dengan baik sebagai pemimpin yang ditugaskan dan pemimpin yang muncul. Dalam artikel ini, pertama penulis akan mendefinisikan konsep kepemimpinan oleh Northouse yang menyatakan adanya dua natur pemimpin, yaitu pemimpin yang ditugaskan dan pemimpin yang muncul. Juga akan menguraikan kaitan antara pelbagai kekuasaan yang berkaitan dengan dua natur pemimpin tersebut. Kedua, penulis akan menyelidiki tokoh Boas yang diungkapkan dalam kitab Rut berdasarkan lensa kedua natur kepemimpinan tersebut dan juga bagaimana Boas menggunakan kekuasaan yang terkait kedua natur kepemimpinan dalam dirinya. Pada akhirnya, penulis akan menyimpulkan 
bahwa Boas adalah seorang contoh dari pemimpin yang ideal dan efektif karena ia dapat menjalankan kedua natur kepemimpinan itu dengan baik. Kunci sukses kepemimpinan Boas ini terletak pada karakter dan ketrampilannya.

Kata-kata Kunci: Boas, Kepemimpinan, kitab Rut, Peter G. Northouse.

\section{Introduction}

The book of Ruth is more than a love story about Ruth and Boaz. We can learn many things from this book. If we read Reading Ruth in Asia, we can find many topics drawn from the book of Ruth, such as the problem of migration or asylum seeker, the relationship between mother-in-law and daughter in law, the excellence of woman, marriage and family, etc. ${ }^{1}$ However, in this book, we can not find the topic of leadership. In recent years there are only three articles about leadership in the book of Ruth. ${ }^{2}$ Based on the story, Ruth and Boaz, Friedman, and Birnbaum share a paradigm for today's CEO, namely showing compassion to others, the importance of corporate philanthropy, kindness to strangers and diversity in the workplace, and women as decision-makers. ${ }^{3}$ John Maxwell writes about the life of Ruth which gives some leadership insights, such as doing what is right, following your heart with integrity, etc. ${ }^{4}$ In his article, Yong Lu explains the leadership characters of Naomi, Ruth, and Boaz. Lu describes Naomi's leadership characters have loyalty to God, discovering value within, patience, and endurance. Ruth's leadership characters contain faithfulness, daring, deference, obedience, etc. Boaz's leadership characters incorporate respect, compassion, empowerment, protecting the weak, moral integrity, etc. ${ }^{5}$ So, Lu only describes the leadership

\footnotetext{
${ }^{1}$ Jione Havea and Peter H. W. Lau, ed., Reading Ruth in Asia (Atlanta: Society of Biblical Literature, 2015).

${ }^{2}$ Hershey H. Friedman and Toby Birnbaum, "The Story of Ruth and Boaz: A Paradigm for Today's CEO," Shepperd Institute Journal of Practical Leadership 6, no. 1 (2012): 1-8, https://ssrn.com/abstract=2157247; John C. Maxwell, Wisdom From Women in The Bible (New York: Faith Words, 2015); Yong Lu, "Leadership Characters in the Book of Ruth: A Narrative Analysis," Journal of Corporate Responsibility and Leadership 3, no. 3 (February 1, 2017): 55-71.

${ }^{3}$ Friedman and Birnbaum, "The Story of Ruth and Boaz: A Paradigm for Today's CEO," $1-8$.

${ }^{4}$ John C. Maxwell, Wisdom From Women in The Bible, 1-17.

${ }^{5}$ Yong Lu, "Leadership Characters in the Book of Ruth: A Narrative Analysis,"
} 55. 
characters, not about the leadership. So, this article will fill this gap by writing about leadership from the book of Ruth. This article is about the leadership of Boaz. This article is about examining the leadership of Boaz in the book of Ruth by the leadership concept of Peter G. Northouse. Based on Northouse's concept, Boaz is an ideal and effective leader who can perform both as assigned and emergent leaders. The keys to the success of Boaz's leadership are his character and skills.

\section{Peter G. Northouse's Concept of the Nature of Leadership}

Peter G. Northouse defines leadership as a process whereby an individual influences individuals to achieve a common goal. ${ }^{6}$ This definition consists of three essential aspects of leadership, namely process, influence, and common goal. ${ }^{7}$ Northouse also explains the nature of leadership, such as a trait or process leadership, assigned or emergent leadership. ${ }^{8}$ He details the types of power in leadership, such as referent, expert, legitimate, reward, coercive, and information. ${ }^{9} \mathrm{He}$ argues about two major kinds of power: position and personal. Position power is related to assigned leadership: the leader's power derives from having a title or position in a formal organization system. This kind of power includes legitimate, reward, information, and coercive power. Personal power is associated with emergent leadership that includes referent and expert power. ${ }^{10}$

Some scholars mention these two natures of leadership as formal leadership and informal leadership and tend to consider constant

${ }^{6}$ Peter G. Northouse, Leadership Theory and Practice, Seventh Edition (California: SAGE Publications, Inc., 2015), 6.

${ }^{7}$ Northouse, 6-7.

${ }^{8}$ Ibid., 7-10.

${ }^{9}$ Ibid., 9-1l. Northouse adapted these concepts from J.R. French Jr. and B. Raven in "The Bases of Social Power," in D. Cartwright (ed.), Group Dynamics: Research and Theory. New York: Harper \& Row, 1962, 259-269; and B. H. Raven, "Social Influence and Power," in I. D. Steiner \& M. Fishbein (Eds.) Current Studies in Social Psychology. New York: Holt, Rinehart \& Winston, 1965, 371-382. Northouse explains referent power based on followers' identification and liking for the leader; expert power - based on follower's perceptions of the leader's competence; legitimate power - associated with having status or formal job authority; reward power - derived from having the capacity to provide rewards to others; coercive power - derived from having the capacity to penalize or punish others; and information power - derived from possessing knowledge that others want or need.

${ }^{10}$ Ibid., $11-12,16$. 
potential conflicts between two types of leadership. ${ }^{.1}$ Northouse does not mention these potential conflicts because he describes the two natures of leadership in having and exercising many types of power in leadership. We do not need to oppose these two natures of leadership because someone can perform both as an assigned and an emergent leader.

\section{Method}

This article focuses on the examination of Boaz as one of the main characters in the book of Ruth. This article will apply the character analysis by giving intention to the direct description of the character by the narrator, the action, and the character's speech. ${ }^{12}$ Then there is an exploration of the result of character analysis to examine the leadership of Boaz. The concept of Northouse will examine the nature of Boaz's leadership and how he performed the many types of power as a leader and the key success of his leadership.

\section{Result and Discussion}

Based on Northouse's definition of the nature of leadership, Boaz could be categorized both as an assigned leader and also as an emergent leader. As the owner of the field, Boaz is an assigned leader. He appointed or assigned himself as the leader. On the other hand, although Boaz was an outstanding person in society, he was not mentioned as the city's elder. He did not have a formal position in society. His character and action set off society to regard him as an emergent leader. Therefore, Boaz is both an assigned leader and also an emergent leader.

${ }^{11}$ C. Dean Pielstick, "Formal vs. Informal Leading: A Comparative Analysis," Journal of Leadership Studies 7, no. 3 (September 14, 2000): 99-114, accessed April 22, 2021, http://journals.sagepub.com/doi/10.1177/107179190000700307; Dorien Van De Mieroop, Jonathan Clifton, and Avril Verhelst, "Investigating the Interplay between Formal and Informal Leaders in a Shared Leadership Configuration: A Multimodal Conversation Analytical Study," Human Relations 73, no. 4 (April 25, 2020): 490-515, http://journals.sagepub.com/doi/10.1177/0018726719895077. 47-86.

${ }^{12}$ Shimon Bar-Efrat, Narrative Art in the Bible (Decatur: The Almond Press, 1989), 


\section{Boaz as an Assigned Leader}

The narrator described Boaz as the owner of the field (Ruth 2:3). By reading the further story, we got the impression that Boaz was a wealthy and prominent landowner. Goldingay explains that there is a suspicion for being the prominent landowner because the book of Joshua portrays how The Israelites distributed the land among the clans and families. Hence, there were not assumed to be big landowners. There were not supposed to be people who were employees of other people. Maybe Boaz has done well out of the famine to take control of other people's land. ${ }^{13}$ Boaz not only survived, but he also succeeded through the famine and became a prominent landowner.

As the owner of the field, Boaz is an assigned leader. He appointed or assigned himself as the leader. Boas had power as an assigned leader, including legitimate, reward, information, and coercive power. By examining the story in the book of Ruth, we could find how Boaz acted as an assigned leader with many types of power.

Boaz had legitimate power because he was the landowner. He owned a significant portion of land. He also had many workers to do farming for him. Boaz had legitimate power over his employees. He managed the rank of his employees. There were regular workers and also the supervisor (Ruth 2:4-5). He showed his skill in managing his employees.

He also had legitimate power over his land produce. He could sell, share or do anything with this product. In connection to Ruth, Boaz exercised his legitimate power by warning his employers not to touch or harass Ruth (Ruth 2:9). Boaz not only had legitimate power, but he exercised it wisely in managing his farm and allowing him to help others.

Boaz also has exercised his reward power among his employees. He had a young man who was in charge of the reapers (Ruth 2:5). Boaz rewarded this young man with a good position because he knew the ability of this young man. This young man became a supervisor for Boaz's employees at a young age. In Ruth chapter 2 , we could also discover that Boaz gave Ruth special treatment for gleaning at his field, protecting his employees, and meal with his workers because he knew every remarkable thing that Ruth did for her mother-in-law. Boaz also asked

${ }^{13}$ John Goldingay, Joshua, Judges \& Ruth for Everyone (Louisville: Westminster John Knox Press, 2011), 171. 
God to bless Ruth because of her good deed to her late husband's family. ${ }^{14}$ In this case, we could say that Boaz also exercised the reward power to Ruth. He rewarded Ruth for her deeds to her late husband's family.

Boas also had the information power. Although he did not know everything, he knew to whom he should ask the critical information. He asked his right-hand man or supervisor. His right-hand man gave him the correct information about his question. His right-hand man or overseer answered the complete information about Ruth (Ruth 2:5-7). ${ }^{15}$ He had enough information about Ruth, so he could plan his future action to achieve his goal.

We could conclude that Boaz as the assigned leaders, had a higher status than his employers and exercised many kinds of power such as legitimate, reward, and information. We could assume that Boaz not only had these powers, but he also implemented these powers prudently in dealing with his farm, employees, and others.

There is another type of power that needs to be explored in the leadership of Boaz, namely coercive power. Did Boaz exercise coercive power? As the owner, he had coercive power over his employees. With this kind of power, Boaz could penalize or punish others. However, the book of Ruth did not show that Boaz employs coercive power.

On the other hand, this book pictured that Boaz had a good relationship with his employees. Boaz greeted his employees with God's blessing, and his employees returned his greeting with God's blessing, too (Ruth 2:4). Goldingay describes that the mutual blessing was a conventional greeting, but it indicated Boaz's relationship with God and his good relationship with his employees. ${ }^{16}$ We could presume that Boaz had a good relationship with his employees. Their relationship is marked with respect to each other. It signified Boaz as a good leader.

In Ruth chapter 3, Boaz went and slept on the threshing floor. Timothy Curtis Snow describes the purposes of Boaz's action were for securing the crop against thieves and preventing the threshing floor from

${ }^{14}$ Peniel C. D. Maiaweng and Christina Ukung, "Apakah Rut, Perempuan Moab Adalah Penyembah TUHAN?," Jurnal Jaffray 16, no. 2 (October 3, 2018): 160-174, accessed April 22, 2021, http://ojs.sttjaffray.ac.id/index.php/JJV7l/index.

${ }^{15}$ Philip F. Esler, "'All That You Have Done ... Has Been Fully Told to Me': The Power of Gossip and the Story of Ruth," Journal of Biblical Literature 137, no. 3 (2018): 645-666, accessed January 26, 2021, https://muse.jhu.edu/article/707963.

${ }^{16}$ Goldingay, Joshua, Judges \& Ruth for Everyone, 171. 
being used for immoral purposes. ${ }^{17}$ This action indicated that Boaz was a good leader who managed his field well to achieve a good harvest and good work environment.

In Ruth chapter 3, Boaz and Ruth encountered a unique encounter during the night on the threshing floor. In verse 9, Ruth asked Boaz to marry her. Daniel I. Block describes that Ruth's request is highly irregular from the perspective of custom; a foreigner proposing Israelite, a young woman proposing an older man, and a poor woman proposing the landowner. ${ }^{18}$ Boaz could say the flippant words to Ruth because he could feel being pushed and seduced by her. ${ }^{19}$ However, as a substitute for offending by Ruth's directness, Boaz could see the excellent character of Ruth and blessed and applauded her as a noblewoman. ${ }^{20}$ In Boaz's mind, Ruth's action and request at the threshing floor demonstrated the greater hesed than her past actions. ${ }^{21}$ Younger Jr. describes that the scene on the threshing floor is sexually provocative. ${ }^{22}$ However, Boaz did not take advantage of Ruth in this weak position. He could see the inner beauty of the vulnerable woman. Alicia Besa Panganiban writes that Boaz is not a typical man; he is a man of honour. ${ }^{23}$ Younger Jr. marks the integrity of Boaz in this case. ${ }^{24}$ This narrative showed the character quality of Boaz.

In the book of Ruth, we did not find that Boaz applied coercive power. It is crucial to evaluate Boaz's leadership quality because Northouse considers the leader who exercises coercive power as not a

17 Timothy Curtis Snow, "Agricultural Dimensions of the Book of Ruth," (Dissertation, Doctor of Philosophy, The Catholic University of America, 2016), 20, https://cuislandora.wrlc.org/islandora/object/cuislandora\%3A60014/datastream/PDF/vi ew.

${ }^{18}$ Daniel L. Block, Ruth. Exegetical Commentary on the Old Testament (Grand Rapids: Zondervan, 2015), 49.

${ }^{19}$ Ibid., 182.

${ }^{20}$ Ibid., 49.

${ }^{21}$ Ibid.; Frederic Bush, Ruth/Esther. Word Biblical Commentary Volume 9 (Dallas: Word Books, 1996) 170-171; Robert L. Hubbard Jr., The Book of Ruth. The New International Commentary on The Old Testament (Grand Rapids: William B. Eerdmans Publishing Company, 1988), 213-215.

22 K. Lawson Younger Jr., Judges, and Ruth. The NIV Application Commentary (Grand Rapids: Zondervan, 2002), 463.

${ }^{23}$ Alicia Besa Panganiban, "Theology of Resilience Amidst Vulnerability in the Book of Ruth," Feminist Theology 28, no. 2 (January 15, 2020): 192, http://journals.sagepub.com/doi/10.1177/0966735019886077.

${ }^{24}$ Younger Jr., Judges, and Ruth. The NIV Application Commentary, 463. 
model of an ideal leader. ${ }^{25}$ It means that we could assume that Boaz is an ideal leader. His employees respected him not only because he was the landowner and the boss or, in other words, an assigned leader. ${ }^{26}$ His employees considered him as a good role model. Boaz gained respect from his employees because of his character, attitude, and action. Not only from his employees, but Boaz also won respect from Ruth and Naomi because of his character, attitude, and action. He did not take advantage of the vulnerable person, but he helped them. Boaz was more than just an assigned leader. He was the assigned leader with excellent character and skills.

\section{Boaz as an Emergent Leader}

Besides an assigned leader, Northhouse also mentions an emergent leader. Someone can be classified as an emergent leader because others identify him or her as the most influential member of a group, organization, or community, regardless of the individual's title or formal position. ${ }^{27}$ The emergent leader becomes known because the community recognizes him or her through his/her certain personality traits and positive communication behaviours. ${ }^{28}$ In other words, the emergent leader relies on personal character and skills. ${ }^{29} \mathrm{He}$ also relates the emergent leader with the social identity theory, which shows that the emergent leader usually fits with the group's identity as a whole and becomes almost like the group prototype. ${ }^{30}$ Then he explains that personal power is associated with emergent leadership that includes referent and expert power. A leader has referent power because people like the leader and consider him or her to be a good role model. A leader has expert power because people view the leader as highly competent. ${ }^{31}$

In Ruth 2:1, the narrator describes Boaz as a worthy man חיר ('îš gibbôr hayil). The Hebrew term (gibbôr) can be translated as

${ }^{25}$ Northouse considers the leader who exercises coercive power as not a model of an ideal leader. Northouse, Leadership Theory and Practice, Seventh Edition, 12-13, 16-17.

${ }^{26}$ Northouse put the referent power belongs to the emergent leader, not to the assigned leader. Ibid., 11-12, 16.

${ }^{27}$ Ibid., 8.

28 Ibid.

${ }^{29}$ Ibid., 9.

${ }^{30}$ Ibid.

${ }^{31}$ Ibid., 10-12. 
"vigorous", "mighty", "influential" or "powerful".32 The Hebrew term (hayil) contains many meanings, such as "strong," "wealthy," "brave," or "of the upper class." ${ }^{33}$ Saxegaard understands "îs gibbôr hayil as a description of Boaz as a man with both economic and social status or "a man of might and honour." 34 D. Ulrich translates 'îs̆ gibbôr hayil as "a man of substance and character" and describes Boaz as a godly man in a spiritually dreary era and a well-to-do resident. ${ }^{35}$ Bush describes that these terms imply not only wealth but also ability and honor. ${ }^{36}$ Hubbard Jr. portrays Boaz as an influential person with wealth, a high reputation, and strong influence among his peers. ${ }^{37}$ Block describes Boaz's economic or political reputation and entitles him as a prominent rich man of noble character. ${ }^{38}$ Fewell and Gunn describe Boaz as a pillar of society because he was an important man in the community, a man of reputation, and social, economic, and moral standing. ${ }^{39}$ The narrator gave Boaz a distinctive description as 'î̌s gibbôr hayil, which indicated his character, wealth, and competency that held the attention of society. Peter H. W. Lau describes Boaz as the prototypical of Israelite, "a man of great worth" (Ruth 2:1), which expressed both in word and action of his vibrant relationship with YHWH. ${ }^{40}$

Based on Northouse's explanation about the emergent leader as the group prototype, ${ }^{41}$ we can also classify Boaz as the emergent leader in society because he fitted with the "true Israelite," which made him attractive and influenced society.

32 Kristin Moen Saxegaard, Character Complexity in the Book of Ruth (Tubingen: Mohr Siebeck, 2010), 149.

33 Saxegaard, 149.

${ }^{34}$ Ibid.

35 D. Ulrich, "Boaz," Dictionary of the Old Testament. Wisdom, Poetry \& Writings. (Downers Grove: IVP Academic, 2008), 32.

${ }^{36}$ Bush, Ruth/Esther. Word Biblical Commentary Volume 9, 100.

37 Hubbard Jr., The Book of Ruth. The New International Commentary on The Old Testament, 133.

${ }^{38}$ Block, Ruth. Exegetical Commentary on the Old Testament, 52.

${ }^{39}$ Danna Nolan Fewell and David M. Gunn, "Boaz, Pillar of Society: Measures of Worth in The Book of Ruth," Journal for the Study of the Old Testament 45 (1989): 46, 54, https://journals.sagepub.com/doi/10.1177/030908928901404505.

${ }^{40}$ Havea \& Lau, "Another Postcolonial Reading of the Book of Ruth," Reading Ruth in Asia (Atlanta: SBL Press, 2015), 18.

${ }^{41}$ Northouse, Leadership Theory and Practice, Seventh Edition, 9. 
It is fascinating that although Boaz was an outstanding person in society, he was not mentioned as the city's elder. Maybe there is any reason that caused Boaz did not hold a formal position, such as the city's elder. Boaz's status of not marriage hindered him from sitting in that position because being married was very important in Israelite society. ${ }^{42}$ Boaz has not ever got married before meeting Ruth.

Ruth 4:2 mentions the elders of the city of Bethlehem. In the Old Testament, there were three types of elders, namely elders of a city (Jdg. 8:14), elders of a tribe (Jdg. 11:5), and elders of the nation (Ex. 3:16). ${ }^{43}$ The primary duties of the elders were judging and ruling. They were serving God to preserve the life of God's people in a covenantal way. ${ }^{44}$ The characteristic of the elders were capable men who feared God and were upright (Ex. 18:21, 25); wise, understanding, and experienced (Deut. 1:13); empowered by the Holy Spirit (Num. 11:16-17). ${ }^{45}$ Elders generally functioned as leaders in war, judges in dispute, givers of wise advice, and witnesses in administration. ${ }^{46}$ Although Boaz was not one of the elders of the town of Bethlehem, he could ask the elders to have a meeting to discuss his matter. (Ruth 4:2 - And he took ten men of the elders of the city and said, "Sit down here." So, they sat down.). It seemed that Boaz arranged the legal meeting. ${ }^{47} \mathrm{He}$ also invited the nearer redeemer to discuss this matter. ${ }^{48}$

The power of arranging the elder's meeting is based on the reputation of Boaz in society. ${ }^{49}$ Society respected him. The community knew him as a man with good wealth and character. This condition confirmed that Boaz showed referent power because society respected him. Although society admired and revered Boaz, he did not misuse their preference. He acted and solved his problem according to the law. In the process of marrying Ruth, Boaz showed his expert power. Boaz

\footnotetext{
${ }^{42}$ Goldingay argues that Boaz was a widower. Goldingay, Joshua, Judges e Ruth for Everyone, 171-172.

43 Cornelis Van Dam, “Elder," Evangelical Dictionary of Biblical Theology (Grand Rapids: Baker Books, 1996), 197.

${ }_{44}$ Ibid.

${ }^{45} \mathrm{Ibid}, 198$.

${ }^{46}$ G. Henton Davies, "Elder in The OT," The Interpreter's Dictionary of the Bible, E-J (Nashville: Abingdon, 1962), 71.

${ }^{47}$ Block, Ruth. Exegetical Commentary on the Old Testament, 207.

${ }^{48}$ Fewell \& Gunn, "Boaz, Pillar of Society: Measures of Worth in The Book of Ruth." 46-53.

${ }^{49}$ Block, Ruth. Exegetical Commentary on the Old Testament, 207.
} 
demonstrated his high competence in dealing with his plan to marry Ruth. Fewell and Gunn take into account the smartness of Boaz in dealing with his effort to marry Ruth. Boaz could secure his reputation in the community, although he wanted to marry a Moabite woman. He talked about redeeming the land and continuing male lineage and property in the public scene. He applied the law of redeeming the land law (Lev. 25:23-28), the levirate marriage law (Deu. 25:5-10), and the inheritance law (Num. 27:1-11). ${ }^{50}$ Fewell and Gunn also consider Boaz as the master of public relations because, in this matter, Boaz got all the credit in redeeming Elimelech's family and marrying Ruth, the Moabite woman, without damaging his reputation..$^{51}$ Safeguard also expresses the clever way of Boaz in marrying Ruth. To protect his reputation from malicious gossip and rumour, Boaz put his intention to marry Ruth, a Moabite widow, into the context of the levirate law. As a Moabite, Ruth is at the same time a benefit because Boaz could use it to keep Mr. Soand-so away; but at the same time, it was a problem because he needed an excuse to marry a foreign woman. In this context, the levirate law was suitable. $^{52}$

As an emergent leader, Boaz demonstrated referent and expert power. His character and action set off society to like and respect him. He also showed expert power by successfully marrying Ruth and redeeming Elimelech's family. Although Boaz did not have a formal position as the city elder, he still showed his referent and expert powers that caused him to be an effective emergent leader. His character and skills helped him to be an effective emergent leader in society.

\section{Boaz is the Ideal and Effective Leader}

Boaz is an ideal and effective leader because he can perform both as an assigned and emergent leader successfully. The keys to the success of Boaz's leadership are his character and skills. Yong Lu extensively describes Boaz's leadership characteristics, such as compassion, trusting God, care, protecting the weak, responsibility, moral integrity and

\footnotetext{
50 Block, Ruth. Exegetical Commentary on the Old Testament, 207-208.

${ }^{51}$ Fewell \& Gunn, "Boaz, Pillar of Society: Measures of Worth in The Book of Ruth," 52-53.

52 Saxegaard, Character Complexity in the Book of Ruth, 162-163.
} 
justness, carefulness, empowerment, partnering, etc. ${ }^{53}$ However, Lu's description of this leadership character blends the character (compassion, care, etc.) and the skills (empowerment, formation, and partnering). It is better to separate between the character and the skills.

The designation as 'îs̆ gibbôr hayil for Boaz (Ruth 2:1) confirmed not only his wealth, but it also validated his excellent character. Panganiban describes Boaz as the role model for those in the privileged positions because, with his wealth and position, he provided care for those in a vulnerable position and acted as God's agent for them. ${ }^{54}$ Boaz is the role model of a leader. His excellent character shined his relation with others, such as his employees and others. He respected his employees, and the employees respected him, too. He did not take advantage of Ruth because of her vulnerable position, but he helped her get a better life and position. Boaz became the fulfiller of God's blessing in Ruth's life. ${ }^{55}$ So we can assume that Boaz has excellent character, such as respect, care, responsibility, moral integrity, etc.

The other key to the success of Boaz's leadership is his skill. He managed his employees well. He was not hesitant to appoint a young man as the supervisor. He applied the principle "the right man at the right place." Although he is not the city elder, he skillfully dealt with redeeming Elimelech's family and marrying Ruth, the Moabite woman, by arranging the meeting with city elders and the near kinsmanredeemer. He skillfully achieved his goal to redeem Elimelech's family and marry Ruth. He not only capably maintained his reputation as 'î̌s gibbôr hayil in dealing these sensitive issues, moreover he was the ancestor of the great king David.

His character and skills enabled him to function prudently both as an assigned leader in the context of his farm and as an emergent leader in society. His character and skills helped in performing many types of power of the leader. He performed the powers as leader perceptively. It seemed that Boaz displayed more personal power (referent and expert power) rather than position power (legitimate, reward, coercive, and 65-67.

${ }^{53}$ Yong Lu, "Leadership Characters in the Book of Ruth: A Narrative Analysis," Ruth," 196.

${ }^{54}$ Panganiban, "Theology of Resilience Amidst Vulnerability in the Book of

55 Maiaweng and Ukung, "Apakah Rut, Perempuan Moab Adalah Penyembah TUHAN?" 170. 
information power).$^{56}$ It signified that Boaz is the ideal and effective leader.

\section{The Implication of Boaz's Leadership in Ministry}

Scholars always mention the importance of the skills and character of the leader to be a successful and effective leader. ${ }^{57}$ Others also emphasize the importance of the spirituality of the leader. ${ }^{58}$ Boaz is a business leader who shows moral leadership in the way he runs his business. ${ }^{59}$ The study of Boaz's leadership is in the same direction. The keys to the success of Boaz as an assigned and emergent leader are his character and skills.

To be an assigned leader or formal leader can be effective in many things because we have authority or power to execute something. However, to be an emergent leader or informal leader also can do many good things for others. The study of Boaz's leadership informs that it does not matter if someone is an assigned (formal) leader or emergent (informal) leader. Moreover, someone can perform both types of leaders as Boaz. The more important aspect is how to exercise many types of power of the leader. It seemed that Boaz displayed more personal power (referent and expert power) rather than position power (legitimate, reward, coercive, and information power). Personal power belongs more to the emergent leader. It goes well with the new trend in leadership. Scholars say that traditionally we usually emphasize the assigned (formal) leadership, but the new tendency goes to the emergent (informal) leadership. ${ }^{60}$ So the study of Boaz's leadership is very relevant for this current situation.

${ }^{56}$ Northouse, Leadership Theory and Practice, Seventh Edition, 12.

${ }^{57}$ Pielstick, "Formal vs. Informal Leading: A Comparative Analysis," 100; Yoseph Christian Thomassoyan and Jermia Djadi, "Kepemimpinan Yesus Kristus Menurut Injil Sinoptik Dan Relevansinya Terhadap Kepemimpinan Rohani Masa Kini," Jurnal Jaffray 9, no. 1 (April 3, 2011): 60-85, accessed April 22, 2021, https://ojs.sttjaffray.ac.id/JJV7l/article/view/9l.

58 Yahya Wijaya, "Kepemimpinan Yesus Sebagai Acuan Bagi Kepemimpinan Gereja Masa Kini," Jurnal Jaffray 16, no. 2 (July 24, 2018): 129, accessed April 22, 2021, http://ojs.sttjaffray.ac.id/index.php/JJV71/index. CEO," 1 .

${ }^{59}$ Friedman and Birnbaum, "The Story of Ruth and Boaz: A Paradigm for Today's

${ }^{60}$ Van De Mieroop, Clifton, and Verhelst, "Investigating the Interplay between Formal and Informal Leaders in a Shared Leadership Configuration: A Multimodal Conversation Analytical Study." 491. 


\section{Conclusion}

Examining the leadership of Boaz in the book of Ruth gives us some important lessons. Generally, we are all at once both an assigned leader and an emergent leader. Such as Boaz, we can also perform both as assigned and also emergent leader effectively. His character and skills helped in performing wisely many types of power of the leader. The keys to the success of both kinds of leadership are the character and skills of the leader. So, Boaz is the example of an ideal and effective leader.

\section{Bibliography}

Bar-Efrat, Shimon. Narrative Art in the Bible. Decatur: The Almond Press, 1989.

Block, Daniel I. Ruth. Zondervan Exegetical Commentary on the Old Testament. Grand Rapids: Zondervan, 2015.

Bush, Frederic. Ruth/Esther. Word Biblical Commentary Volume 9. Dallas: Word Books, 1996.

Van Dam, Cornelis. “Elder.” Evangelical Dictionary of Biblical Theology. Grand Rapids: Baker Books, 1996.

Davies, G. Henton. "Elder in The OT." The Interpreter's Dictionary of the Bible. E- J. Nashville: Abingdon, 1962.

Esler, Philip F. “'All That You Have Done ... Has Been Fully Told to Me':

The Power of Gossip and the Story of Ruth." Journal of Biblical

Literature 137, no. 3 (2018): 645-666. Accessed January 26, 2021. https://muse.jhu.edu/article/707963.

Fewell, Danna Nolan, and David M. Gunn. "Boaz, Pillar of Society: Measures of Worth in The Book of Ruth." Journal for the Study of the Old Testament 45 (1989): 45-59. https://journals.sagepub.com/ doi/abs/10.1177/030908928901404505.

Friedman, Hershey H., and Toby Birnbaum. "The Story of Ruth and Boaz: A Paradigm for Today's CEO." Shepperd Institute Journal of Practical Leadership 6, no. 1 (2012): 1-8. https://ssrn.com/abstract=2157247.

Goldingay, John. Joshua, Judges e Ruth for Everyone. Louisville: Westminster John Knox Press, 2011.

Havea, Jione and Peter H. W. Lau, ed. Reading Ruth in Asia. Atlanta: Society of Biblical Literature, 2015. 
Hubbard Jr., Robert L. The Book of Ruth. The New International Commentary on The Old Testament. Grand Rapids: William B. Eerdmans Publishing Company, 1988.

Lu, Yong. "Leadership Characters in the Book of Ruth: A Narrative Analysis." Journal of Corporate Responsibility and Leadership 3, no. 3 (February 1, 2017): 55-71.

Maiaweng, Peniel C. D., and Christina Ukung. "Apakah Rut, Perempuan Moab Adalah Penyembah TUHAN?" Jurnal Jaffray 16, no. 2 (October 3, 2018): 161. Accessed April 22, 2021. http://ojs.sttjaffray.ac.id/index.php/JJV71/index.

Maxwell, John C. Wisdom From Women in The Bible. New York: Faith Words, 2015.

Mieroop, Dorien Van De, Jonathan Clifton, and Avril Verhelst.

"Investigating the Interplay between Formal and Informal Leaders in a Shared Leadership Configuration: A Multimodal Conversation Analytical Study." Human Relations 73, no. 4 (April 25, 2020): 490515. http://journals.sagepub.com/doi/10.1177/0018726719895077.

Northouse, Peter G. Leadership Theory and Practice, Seventh Edition. California: SAGE Publications, Inc., 2015.

Panganiban, Alicia Besa. "Theology of Resilience Amidst Vulnerability in the Book of Ruth.” Feminist Theology 28, no. 2 (January 15, 2020): 182-197. http://journals.sagepub.com/doi/10.1177/0966735019886077.

Pielstick, C. Dean. "Formal vs. Informal Leading: A Comparative Analysis." Journal of Leadership Studies 7, no. 3 (September 14, 2000): 99-114. Accessed April 22, 2021. http://journals.sagepub.com/doi/10.1177/107179190000700307.

Saxegaard, Kristin Moen. Character Complexity in the Book of Ruth. Tubingen: Mohr Siebeck, 2010.

Snow, Timothy Curtis. "Agricultural Dimensions of the Book of Ruth." Dissertation, Doctor of Philosophy, The Catholic University of America, 2016.

https://cuislandora.wrlc.org/islandora/object/cuislandora\%3A6001 4/datastream/PDF/view

Thomassoyan, Yoseph Christian, and Jermia Djadi. "Kepemimpinan Yesus Kristus Menurut Injil Sinoptik Dan Relevansinya Terhadap Kepemimpinan Rohani Masa Kini." Jurnal Jaffray 9, no. 1 (April 3, 2011): 60. Accessed April 22, 2021. https://ojs.sttjaffray.ac.id/JJV7l/article/view/91.

Ulrich, D. "Boaz." Dictionary of the Old Testament. Wisdom, Poetry e Writings. Downers Grove: IVP Academic, 2008. 
Wijaya, Yahya. "Kepemimpinan Yesus Sebagai Acuan Bagi

Kepemimpinan Gereja Masa Kini." Jurnal Jaffray 16, no. 2 (July 24, 2018): 129. Accessed April 22, 2021.

http://ojs.sttjaffray.ac.id/index.php/JJV71/index.

Younger Jr., K. Lawson. Judges and Ruth. The NIV Application Commentary. Grand Rapids: Zondervan, 2002. 